\title{
多様性を持たせたグループワークによる 汎用的能力の向上とその評価手法の確立
}

Improvement of Generic Skills by Working in Diverse Groups and Establishment of Students' Evaluation Approaches

黒 田 恭 平 $^{* 1}$

Kyohei KURODA
段下 剛 志※2

Tsuyoshi DANSHITA
牧

Shinya MAKI

$\begin{array}{lll}\text { 山口 隆 司※2 } & \text { 市 坪 誠※2 } \\ \text { Takashi YAMAGUCHI } & \text { Makoto ICHITSUBO }\end{array}$

\begin{abstract}
A global and innovative human resource development is essential in recent Japanese industry because of rapid globalization of today's world. To address the needs in the industries, we performed the development program of innovative and global human resources in collaboration with 11 "Kosen" during Dec. 26-28, 2015. A total of 35 students and 8 professors in "Kosen" and Nagaoka University of Technology participated in this program. Through the hackathon-based facilitation and project management exercises, we grouped 6 teams, and evaluated students' generic skills improvements. By using spearman's correlation test and network analysis, we could visualize the students' development and interaction in each team. Besides, we propose that diversities of their educational institutions/majors and numbers of female students are the critical factors for effective team building based on principal component analysis of students' diversities.
\end{abstract}

Keywords : Active Learning, Generic Skills, Diversity, Statistical Analysis, Engineering Design キーワード：アクティブラーニング, 沉用的能力, 多様性, 統計解析, エンジニアリング・デザイン

\section{1.はじめに}

高等専門学校 (以下, 高専) と長岡技術科学大学, 豊橋技術科学大学（以下，技科大）は，それぞれ実践 的技術者と高度な指導的実践的技術者を育成すること を目指して設立された ${ }^{1)}$ ）。高専の教育方法は，日本 の高度経済成長期から昨今まで産業のニーズに応えた 人材育成という点で評価されていると共に, 米国から も同様に評価されている ${ }^{3), 4)}$. 国際交流においても, 海外から高専への受け入れ者数, 高専から海外への派 遣者数などを着実に伸ばしている ${ }^{5)}$.

こうした中, 近年は企業の急速なグローバル化が進 んでいる，企業のニーズに応えるため，平成24年度か ら全国の高専と長岡技科大・豊橋技科大が連携して, 世界で活躍するイノベーション人材育成を目的とした 三機関連携事業が行われている ${ }^{6)}$. 加えて平成 26 年度 には，長岡技科大，豊橋技科大ともに「スーパーグロ 一バル大学創成支援」に採択された ${ }^{7)}$. 特に, 長岡技 科大ではその一環として平成 27 年度より，「世界で活

2016 年 6 月 23 日受付

※ 1 北九州工業高等専門学校

※2 長岡技術科学大学
躍する，イノベーションを起こす能力を持ったリーダ 一」を育成することを目的に，5年一貫制博士課程で ある技術科学イノベーション専攻を創設しており，イ ノベーション人材育成に積極的に取り組んでいる.

技科大に進学した高専卒業生の大きな特長として, 学生間の意思疎通の優秀さが報告されている ${ }^{8)}$. 異な る地域で育ってきた高専生同士の強い結びつきは, 新 たな視点を生み出すことにつながり，イベントやプロ ジェクト等を企画・推進する際に大きな強みとなる. 加えて, 長岡技科大は積極的な国際交流を進めており, 2016年 3 月現在で, 留学生の割合が全学生の約 $13 \%$ ま で達していることから, 日本人学生が日常生活の中で グローバルな視点を取り入れることができる環境であ $3^{9)}$. そのため, 意思疎通・国際交流の場を技科大生 だけでなく, 高専生にも広げることで, 地域・年齢・ 国籍を超えた学生の融合が可能となり，イノベーショ ン人材育成に繋がると考えられる.

そこで，意思疎通・国際交流できる“場”として， チーム間で企画・プレゼンテーションを行い, 勝者を 決定するハッカソン型演習10,11) を取り入れた「イノベ ーションアイディアデザイン特別合同演習」を長岡技 科大で開催した。本報では, 高専と技科大という「学 
校間」のつながりから, さらに一歩踏み达んだ，高専 生と技科大生という「学生間」のつながりによって起 こった, 地域・年龄・国籍が異なる学生同士の“化学 反応”について報告する。

\section{2. 合同演習の実施内容}

2. 1 合同演習の概要

本合同演習では，2015年12月26-28日にかけて 3 日 間行った。本合同演習では，中村らによって提案され たカスケード型教育モデル（技学教育モデル）を起こ すことが可能なイノベーション指向型グローバル人材 を“リーダー”として育てることを目的とした ${ }^{11)}{ }^{12)}$. カスケード型教育モデルとは，学生が講義・演習など を体験すると，次からは自発的に行動を起こすことが できる，アクティブラーニングを促す教育モデルであ る。こういったカスケード反応を起こすためには，学 生の分野横断的能力を向上させることが必要不可欠で ある。本合同演習では，国立高専機構が作成したモデ ルコアカリキュラムに定められている技術者が備える
ベき分野横断的能力を向上させるため， 3 日間のプロ グラムを作成した ${ }^{12)}$ (図 1 )。 。た，3 日間のプログラ ムの様子はビデオ撮影により記録した。
[1 日目】

重要視した能力 : コミュニケーションカ, 合意形成力, 協調・協力

9:00-12:00 アイティア創出 (PEST, SWOT 分析) の基本講座

13:00-14:30 イノベーションアイティィア交流会とグルーブ編成

14:40-15:40ファシリテーションの基本講座

15:40-17:40ファシリテーション演習 (アイティアの拡張)

【2 日目】

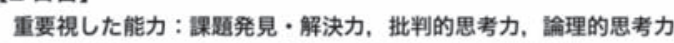

9:00-12:00プロジェクトマネジメントの基本講座

13:00-16:30 PEST. SWOT分析を活用したアイディアの掘り下げと

16:30-17:40アイディアブレゼンテーション (日本語)

$\begin{array}{ll}\text { 夜間 } & \text { SNS (Googleグループ. Skype) を活用した } \\ \text { 英語ブレゼンテーション準備 }\end{array}$

[3 日目]

重要視した能カ : エンジニアデ゙インカ

9:00-11:00アイディアブレゼンテーション (英語)、レビュー

表 1 合同演習の参加学生の概要

\begin{tabular}{|c|c|c|c|c|c|c|c|c|}
\hline 学生No. & 所属 & 学年 & 性別 & 専門 & 国籍 & 役割 & チーム & アイディア \\
\hline 1 & N高専 & 4年 & 女 & 生物・化学系 & 日本 & リーダー & A & 特産品の改良・宣伝 \\
\hline 2 & $F$ 高專 & 4年 & 男 & 機械工学系 & 日本 & ファシリテーター & & \\
\hline 3 & O高專 & 1年 & 女 & 生物·化学系 & 日本 & & & \\
\hline 4 & O高専 & 2年 & 男 & 情報工学系 & 日本 & & & \\
\hline 5 & A高專 & 3年 & 男 & 䉓気情報工学系 & 日本 & & & \\
\hline 6 & 長岡技科大 & 博士課程1年 & 男 & 情報経営システム工学系 & Sri Lanka & & & \\
\hline 7 & O高専 & 5 年 & 男 & 情報工学系 & 日本 & リーダー & $B$ & 観光サービス \\
\hline 8 & 長岡技科大 & 修士課程2年 & 女 & 生物·化学系 & 日本 & ファシリテーター & & \\
\hline 9 & O高專 & 1年 & 男 & 情報工学系 & 日本 & & & \\
\hline 10 & K高専 & 4年 & 男 & 機械工学系 & 日本 & & & \\
\hline 11 & 長岡技科大 & 博士課程1年 & 女 & 情報経営システムエ学系 & Sri Lanka & & & \\
\hline 12 & 長岡技科大 & 博士課程 1 年 & 男 & 土木環境系 & Sri Lanka & & & \\
\hline 13 & G高專 & 4 年 & 男 & 電子制御工学系 & 日本 & リーダー & $\bar{C}$ & 機械メンテナンス \\
\hline 14 & G高専 & 3年 & 男 & 土木環境系 & 日本 & ファシリテーター & & \\
\hline 15 & G高專 & 4年 & 女 & 土木環境系 & 日本 & & & \\
\hline 16 & |高専 & 4年 & 男 & 電子制御工学系 & 日本 & & & \\
\hline 17 & C高専 & 4年 & 男 & 電気情報工学系 & 日本 & & & \\
\hline 18 & 長岡技科大 & 修士課程 1 年 & 女 & 電気情報工学系 & Qatar & & & \\
\hline 19 & 長岡技科大 & 修士課程1年 & 男 & 土木環境系 & Sri Lanka & & & \\
\hline 20 & 長岡技科大 & 修士課程 1 年 & 男 & 機械工学系 & India & & & \\
\hline 21 & O高専 & 2年 & 女 & 情報工学系 & 日本 & リーダー & D & 言語サービス \\
\hline 22 & $\mathrm{H}$ 高専 & 3年 & 男 & 機械工学系 & 日本 & ファシリテーター & & \\
\hline 23 & H高專 & 4年 & 男 & 機械工学系 & 日本 & & & \\
\hline 24 & 長岡技科大 & 学部3年 & 男 & 土木環境系 & 日本 & & & \\
\hline 25 & 長岡技科大 & 博士後期課程 3 年 & 女 & 土木環境系 & Nepal & & & \\
\hline 26 & U高専 & 3年 & 男 & 機械工学系 & 日本 & リーダー & $\bar{E}$ & 地域おこし \\
\hline 27 & C高專 & 4年 & 男 & 電気情報工学系 & 日本 & ファシリテーター & & \\
\hline 28 & 長岡技科大 & 修士課程1年 & 男 & 電気情報工学系 & 日本 & & & \\
\hline 29 & 長岡技科大 & 修士課程1年 & 男 & 土木環境系 & 日本 & & & \\
\hline 30 & 長岡技科大 & 博士後期課程 1 年 & 男 & 土木環境系 & Sri Lanka & & & \\
\hline 31 & W高專 & 5 年 & 男 & 生物·化学系 & 日本 & リーダー & $\bar{F}$ & 特産品の改良・宣伝 \\
\hline 32 & K高専 & 専攻科 1 年 & 男 & 機械工学系 & 日本 & ファシリテーター & & \\
\hline 33 & H高専 & 5 年 & 男 & 機械工学系 & 日本 & & & \\
\hline 34 & 長岡技科大 & 博士後期課程 1 年 & 男 & 土木環境系 & 日本 & & & \\
\hline 35 & 長岡技科大 & 修士課程1年 & 女 & 土木環境系 & Malaysia & & & \\
\hline
\end{tabular}


災害対策服飾（1）

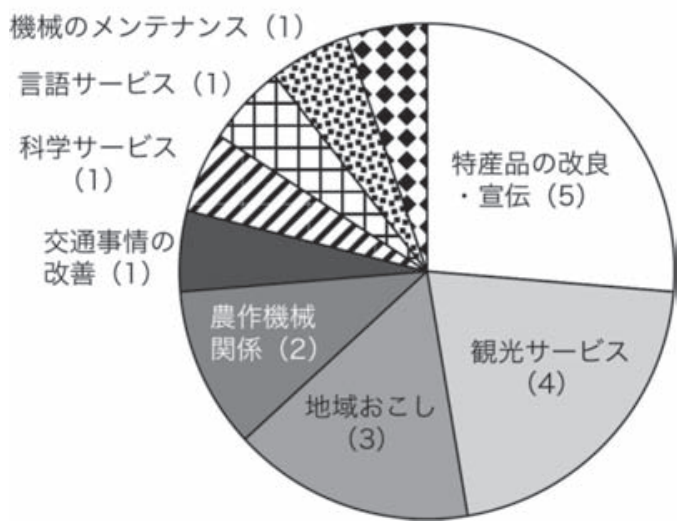

図 2 事前課題の提出状況

（）はアイデイアの数を示す.

本合同演習には，全国11高専から21名，長岡技科大 から 14 名の学生が参加した (表 1 ). 高専の 1 年生から 長岡技科大の大学院博士後期課程 3 年までの幅広い年 代，日本人学生だけでなく 5 力国 9 名の留学生も本合 同演習に参加することで，多様性を担保した。国籍， 学年, 専門・学科を超えた学習は, 学生にグローバル な視点など多面的視点を持たせるだけでなく，学生間 の “化学反応”による分野横断的能力向上の相乗効果 が期待される.

参加学生には,「地元の地域産業を活性化させるイ ノベーションアイデイア考案」を事前課題として与え た. 結果，19個（9種類に分類）のアイデイアが提出 された (図 2 ).

2.2 ファシリテーション基礎講座・演習（1日目）

1 日目の朝は, 参加学生が 1 名ずつ事前課題を口頭 で発表し, 教員 8 名が学生にコメントやサジェスチョ ンを行った，加えて，35名の学生と 8 名の教員が良か ったアイディアに対して投票を行い, 得票数の多いも のから6つの「イノベーションアイディア」を決定し た（図 1 , 表 1 ).

6つのイノベーションアイデイアの決定後は, ファ シリテーション及びロジカル・シンキングやマーケテ イング手法としてマクロ環境（PEST，世の中で一般 的に起こっている状況，現象，事実を分析する方法) 分析・SWOT分析 (内部・外部環境分析結果をそれぞ れプラス，マイナス要因に分割して現状を把握する方 法）の基礎講座を行った。 ファシリテーションは，プ ロジェクトチームの “リーダー”として, 議論の活性 化やチームを協調させ, 目標に到達させるために必要 不可欠な技術である。ファシリテーターには，コミュ ニケーションスキルは勿論のこと, 合意形成能力や協 力, 協調する力, 論理的思考力などが必須である. 加 えて, 学生にPEST 分析・SWOT 分析を学ばせること で, 批判的思考力, 課題発見·解決力, 論理的思考力, 情報収集力の向上を促した.

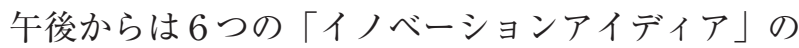

うち，最も実現したいアイディアを選ぶことで，チー ム編成を行った（1チーム $5-8$ 名, 表 1$)$. 具体的に は, 高専生・長岡技科大生 (日本人) に, 最も実現し たいアイディアを選ばせ, 各チームの留学生が 1 名以 上になるように長岡技科大留学生を配属した。 Aチー ム以外のチームリーダーは, 事前課題発案者となった ため, ファシリテーターにはリーダーと異なるメンバ 一が担うように指示し, 各チームの「イノベーション アイディア」を実現するための議論を行うことで, 発 表を行うための資料（PEST・SWOT分析結果）の作 成を指示した (ハッカソン型演習)。また,リーダーに は意思決定を行い, チームの方向性を導くように指示 した. 1 日目の最後に, 各チームが議論した結果を日 本語で発表し, それに対して8名の教員がコメントや サジェスチョンを行った。1日目の夜には, 各チーム でGoogleグループやSkypeなどのSNSを使用すること により，チーム間の議論や情報共有を促した.

2.3 プロジェクトマネジメント講座・演習 (2, 3 日目)

2 日目の午前中は, プロジェクトをマネジメントす るために必要な知識・技術として, ビジネスにおける ニーズの把握, シーズの考え方とプレゼンテーション 技術の講座を行った. 2 日目の午後からは，1日目に 各チームが考えた「イノベーションアイディア」を， PEST 分析・SWOT 分析を駆使しながら更に深く解析 し, その結果を日本語のプレゼンテーション資料とし てまとめる作業を学生が行い, 発表を日本語で行った. また，その発表に関して6名の教員がコメントやサジ エスチョンを行った. 2 日目の夜には, 各チームでSNS を使用させ， 2 日目の午後に作成した日本語のプレゼ ンテーション資料を英語に翻訳し, 90秒で発表（英語） するための準備を指示した。 3 日目は, 各チームで作 成したプレゼンテーション資料を英語で発表させ，そ れに対して 6 名の教員がコメントやサジェスチョンを 行った。 また, 教員間での協議の結果, 上位 2 チーム を優秀チームとして表彰した。

\section{3. 学生の成長度合いの評価基準}

本合同演習では, 技術者の備えるべき分野横断的能 力の向上を目的とし， 5 種類のアンケート調査（アン ケートA， B， C，D，E）を各日の終りに計 3 回実施 した。 アンケート A, Bの汎用的能力は, 国立高専機 構が作成したモデルコアカリキュラムを参考に, 中 村らが決定した項目を用いた (図 $3 \mathrm{~A}, \mathrm{~B})^{8)}$. アンケ 一トAに関しては, 自己評価だけでなく, 各チームメ ンバーの評価も行うよう指示した (他己評価)。アン ケートCと Dは， 1 - 3 日目の夜間演習時に使用した ソーシャルネットワーク（SNS）などの情報通信技術 （ICT）活用の成果を評価した（図 $3 \mathrm{C} ， 3 \mathrm{D})$. 本プロ グラムで得られたスキルを評価するために，ファシリ 


\section{アンケート A : 汎用的な能力 10 項目の自己・他己評価}

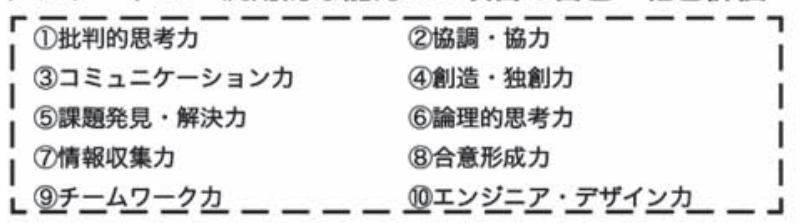

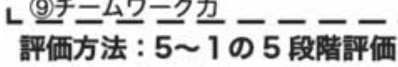

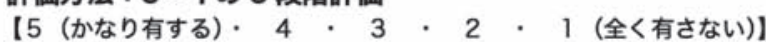

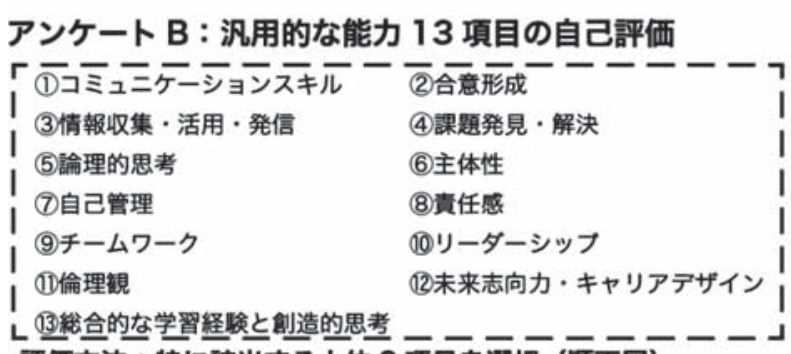

評価方法 : 特に該当する上位 3 項目を選択 (順不同)

\section{アンケート C}

: SNS を活用したグループワークに関する自己評価

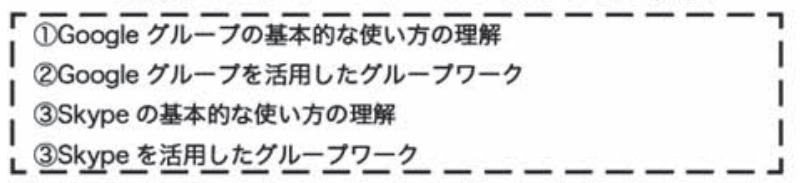

ᄂ 評価方法: 5〜 1 の 5 段階評価

【5（不自由なく使えるようになった，かなり役立った）・ 4 ～～ 3 $2 \cdot 1$ (全く使えなかった, 全く役立たなかった $) 1$

\section{アンケート D \\ : SNS の活用による汎用的な能力 13 項目の向上への効果

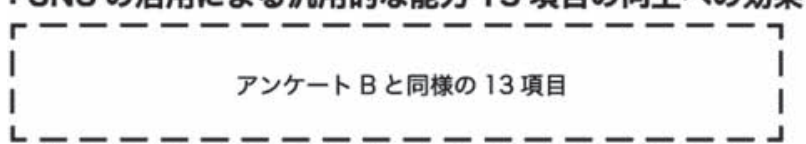

評価方法: 特に向上したと感しる上位

\section{アンケート E : プロジェクトの参加によるスキル向上の効果 「『ファシリテーションの基本を理解し実践てきたかーーーーフ

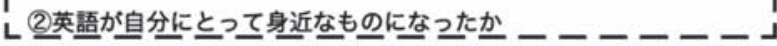 評価方法 : 5 1の 5 段晆評価

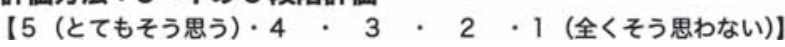

図 3 アンケートの評価項目

$\mathrm{A}$ : 沉用的能力 10 項目, B : 汎用的能力 13 項目, $\mathrm{C}$ : SNSを活用したグループワークに関する 4 項目， D : $\mathrm{SNS}$ の活用により向上した沉用的能力 13 項目, E : プログラム参加によるスキル向上の効果

テーション能力と英語能力に関してアンケートEを行 った (図 $3 \mathrm{E}$ )。加えて，学生の率直な意見を聞くため に，自由記入の欄も設けた。 アンケートAの他己評価 は，PASTソフトウェアを用いてチームごとに 3 日間 のデータの変遷をSpearman's correlationテストで解 析を行った $\left(r s>0.35, \mathrm{p}^{-} \text {value }<0.05\right)^{13)}$. Spearman's correlationテストの結果はCytoscapeで可視化した ${ }^{14)}$. チームの人多様性を評価するために, チーム内の A. メ ンバー数, B. 学科の種類, C. 留学生の数, D. 学年の 数, E. 学校の種類, F. 男性の数, G. 女性の数を用いて Principal Component Analysis（PCA）を行った。解 析ソフトウェアには, PastProjectを用いた ${ }^{13)}$.

\section{4. 合同演習の結果}

1 日目の「地域産業を活性化させるイノベーション アイディア」の発表を行った結果, 各地域に応じた多 様なアイディアが19個提案された（図 2 ）。このうち, 学生・教員による投票の結果,「特産品の改良・宣伝」 から 2 個,「観光サービス」から 2 個, 「機械のメンテ ナンス」から 1 個,「地域㧍こし」から 1 個の計 6 個が 上位となり, これらアイデイアのうち, 最も実現した いアイデイアを各々の学生が選ぶことで, チームを形 成した（表1）。

ファシリテーション基礎講座では，まずアイディア 構築の基本として, SWOT分析・PEST分析の重要性 を学生に伝えることで, ビジネスとしてどのようにセ グメンテーション・ターゲティングを行うべきなのか を考えるように働きかけた，加えて，ファシリテータ 一として最も重要な点“ファシリテーターは自身の意 見を言わず，他の参加者から意見を引き出し，議論を 活性化させる役割”という意味を学生に認識させた. ファシリテーション演習では, ファシリテーターを各 チームで決め, 学生がファシリテーションを行うこと で, チームのアイディアを活発に議論させた。 その結 果, 時間の限られた状況においても, 学生はSWOT分 析・PEST分析を行い，それを口頭で発表した。

2 日目のプロジェクトマネジメント講座は, アイデ イア構築のために欠かせない, ビジネスのニーズの把 握・シーズの考え方を重点的に行った. 特に, グローバ ルな視点から, 海外のマーケティングを把握し, その アイディアをどのように海外に展開することができる か，という点に着目して講座を行った，また，実際に 海外のプレゼンテーション (英語) を学生に視聴させ, 英語でプレゼンテーションするために考慮する必要が ある事項を認識させた。 2 日目午後から 3 日目までの プロジェクトマネジメント演習では, 各チームで選ん だアイデイアを哚く議論させ，それを投資家や企業の 前で発表するという仮定の前提条件を付け，90秒間の 英語プレゼンテーション資料の作成を指示した，学生 は 2 日目午後のグループワーク，2 日目夜間のSNSを 用いたグループワークにより, 留学生ともコミュニケ ーションを取りながら，プレゼンテーション資料を完 成させ， 3 日目に全グループが発表を英語で行うこと ができた。 プレゼンテーション後, 教員間で協議し, 6 チームのうち, “チームA”と“チームB”を優秀チ ームとして表彰した。

全体のプログラムを通した学生の感想を図 4 に示す. 1 日目は,「異なる地域から来た学生間・留学生とのコ ミュニケーションを持てたこと」が全体の回答の $48 \%$ を 占めた。 また，1日目に行ったファシリテーション講座 の成果として,「イノベーションを起こすためのスキル が向上した」が $26 \%$ と 2 番目に高い值を示した。 2 日目 は, プレゼンテーションを行うためのグループワークが 


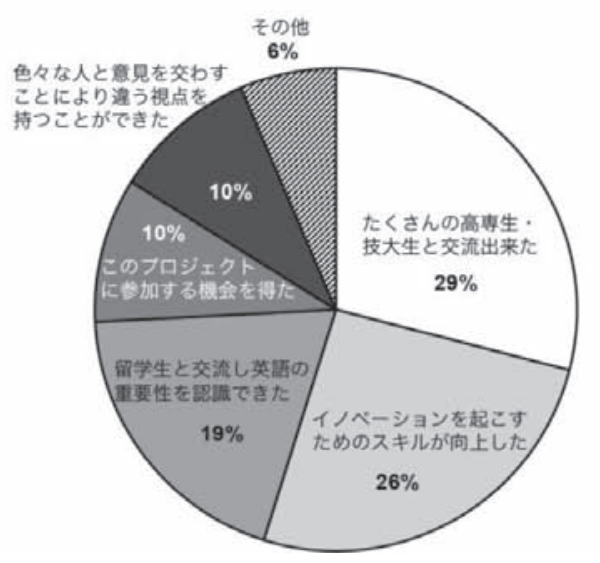

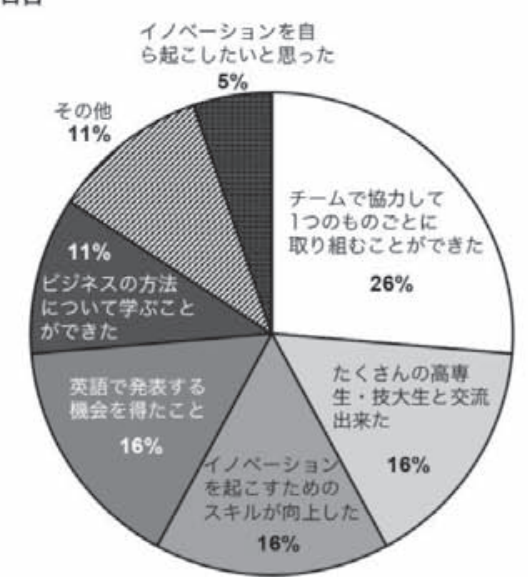

C. 3 日目

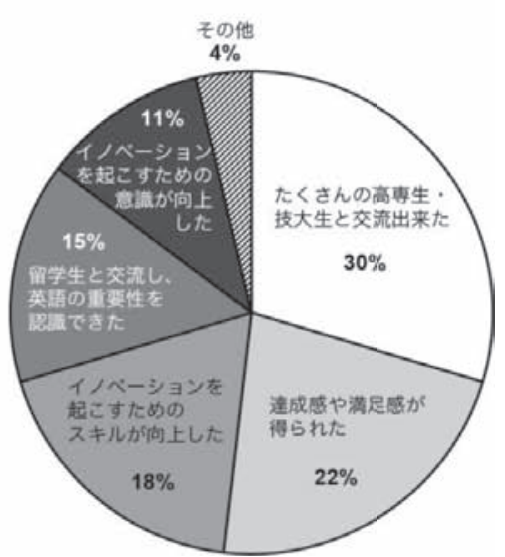

図4 アンケート自由記入欄の感想

A：1日目, B：2 日目, C : 3 日目

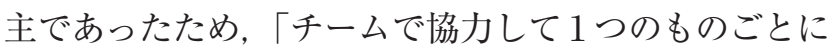
取り組むことができた」が $26 \%$ と 1 番高かった。 $1-3$ 日目に扮いて，「イノベーションを起こすためのスキル が向上した」が上位を占めていたが，3 日目のアンケー トでは, それに加えて「イノベーションを起こすための 意識が向上した」が $11 \%$ 占め, イノベーション指向型 の人材が育っていることが示唆された。

\section{5. 汎用的能力の教育効果と考察}

本プログラムの教育効果を測るために， $1-3$ 日目 の終わりに 5 種類のアンケートを行った(図 3 ). 図 5 は，アンケートAの汎用的能力10項目の自己評価の全 体平均を示す。 1 日目から 2 日目にかけて, 特に(7)情 報収集力，(8)合意形成力，(10エンジニアリング・デザ イン力の能力の向上が顕著であった. 2 日目から 3 日 目にかけては，(3)コミュニケーション力と (4)創造・独 創力の向上が顕著であった. $1-3$ 日目を通した場合 は，(2)協調・協力以外の項目の能力向上が見られた. 1 日目から 2 日目において能力が向上した「合意形成 力」,「情報収集力」は，ファシリテーションの基礎講 座・演習により期待される効果と一致している ${ }^{15)}$. 加 えて，自らのアイデイアを具現化するためのプロジェ クトマネジメントを学生が学び・実行することで，「エ ンジニアリング・デザインカ」の向上にも繋がったと 考えられた，2日目から 3 日目にかけては，プレゼン テーション資料の作成及び発表がプログラムの主であ ったために，「コミュニケーション力の向上」が見ら れた。加えて，3 日間を通じて形成された新しい人間 関係により，異なる視点からなる意見を取り入れるこ とで，「創造・独創力」の向上が相乗的に起こったの ではないかと考えられた，実際，自由記入のアンケー トに抒いても，「違う視点を持つことができた」，「イ ノベーションを起こすためのスキルが向上した」など のコメントが多数得られている(図 4 )。 プロジェク トマネジメントには,「専門性」,「新しいものを作り
出す力」,「状況を分析する力」,「コミュニケーション 力」,「モチベーション」が必要であることが報告され ており ${ }^{16)}$, 今回の学生の能力向上の結果から, 学生が プロジェクトマネジメントを行うための基礎能力を身 につけることができたと考えられた。

図 6 は, 汎用的能力 13 項目の自己評価の全体平均を 示す。 3 日間を通して,「(1)コミュニケーションスキ ル」,「9チームワーク」,「8責任感」,「(4)課題発見・ 解決」,「(3)情報収集・活用・発信」が高い值を示した。

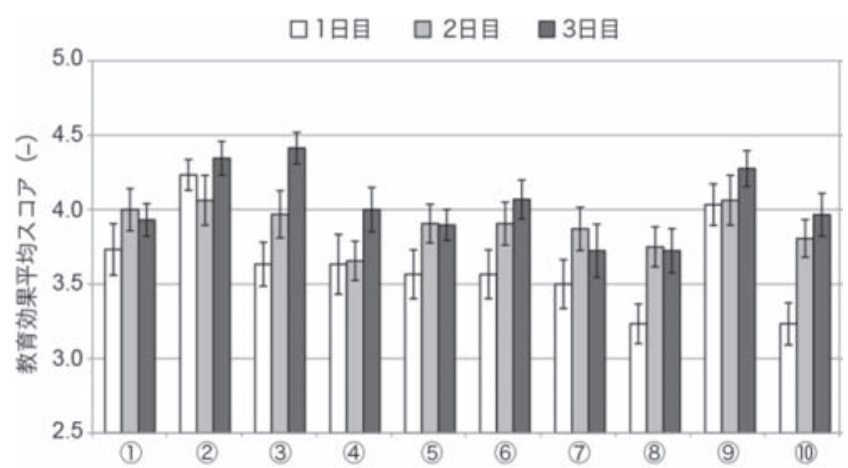

図 5 アンケート A : 汎用的能力10項目の自己評価 (全体) (1)-(10の番号は図 $3 \mathrm{~A}$ の項目を示す.

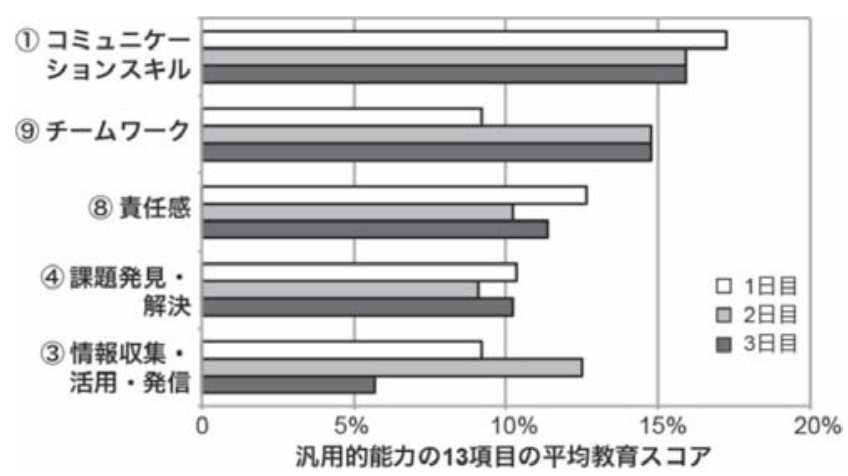

図 6 アンケートB : 沉用的能力 13 項目の自己評価（全体） (1), 9, 8, 4), (3)の番号は図 $3 \mathrm{~B}$ の項目を示す. 
A. チーム $A$

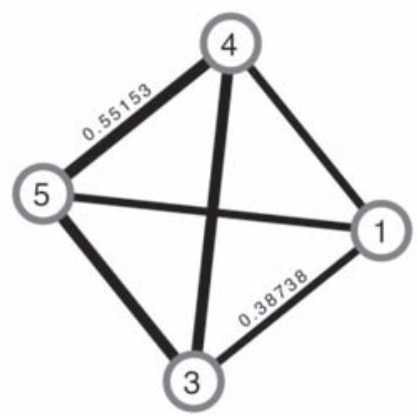

D. チーム D
B. チームB

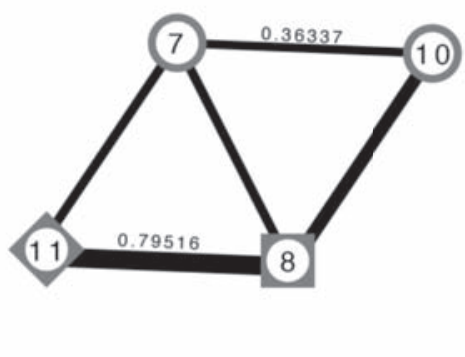

E. チーム $E$
C. チーム C

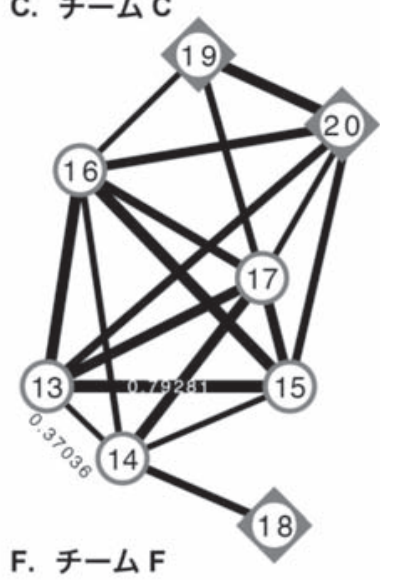

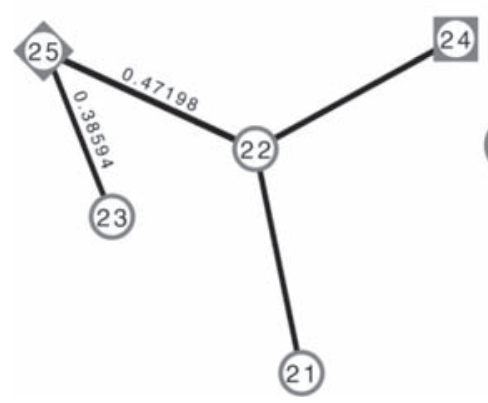

(27)
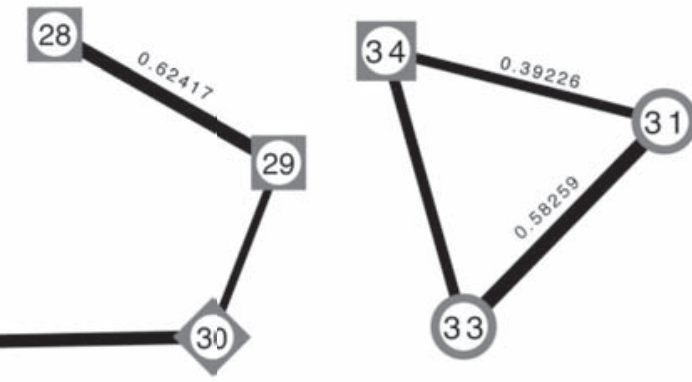

(26)

33

図 7 アンケートAの汎用的能力10項目の他己評価を基にした学生のネットワーク解析結果（各チーム）

$\mathrm{A}$ : チーム $\mathrm{A}, \mathrm{B}:$ チーム $\mathrm{B}, \mathrm{C}$ : チームC, D : チーム D, E : チーム $\mathrm{E}, \mathrm{F}:$ チーム F. ネットワーク解 析は, Spearman's correlationテストにより行った $(r s>0.35, \mathrm{p}<0.05)$. (1)-(34)の数字は表 1 における 学生の番号を示す。図形の丸は高専生, 四角は長岡技科大生（日本人), ひし形は長岡技科大留学生を示 す. 線の太さは他己評価の相関の強さを表し, 線が太い場合は相関が強い. 線の色が黒い場合は正の相関, 灰色の場合は負の相関とした。線の近くに示した值は各ネットワークrsの最大・最小值を示した。学生 No.2，9，12，32は，有意な相関が見られなかったため, 図に示していない. 学生No. 6 と 35 は，本プ ログラムに参加していない日（それぞれ 2 日目と 3 日目）があったため解析から除外した.

学生は，3 日間のほとんどをチームとして行動し,“イ ノベーションアイディア構築”に取り組んだため，グ ループワークとして必要な(1)，(9)，(8)が高い值を示し たと考えられた。 また，今回行ったファシリテーショ ンの基礎講座・演習及びプロジェクトマネジメント講 座・演習により, (3)と(4)の能力を発揮または向上した 学生が多かったのではないかと推測された。

図 7 は, 3 日間における沉用的能力10項目の他已評価 デー夕を基にして，それぞれ 6 チーム内の学生の正負 の相関を持つネットワーク解析結果を示す. 優秀チー ムとして選ばれた“チームA”と“チームB”はメンバ 一のほとんどがバランスよく正の相関を示している(図 7 A, B) 一方で, “チームC” と優秀チーム以外のチー ムは, 学生同士で正の相関があまり見られない, もしく は, 1 人の学生が中心となって正の相関が存在する状 態になっていた（図 7 D, E, F)。そのため, “チーム A”と“チームB” では学生間の活発なインターラクシ ヨンにより,相乗効果で汎用的能力の向上が見られたの ではないかと推測された。“チームC”は他のチームと 比較して多くの正の相関が見られ, 相乗効果による能 力向上が観測された一方で, グループのメンバーが 8 名と多かったため, ファシリテーターの負担が大きくな
ったことが，最終発表の結果に繋がったのではないか と考えられた。“チームD”の学生No.22（ファシリテー ター）は, 他の学生の中心となって正の相関を示してい る (図 $7 \mathrm{D})$. このため, このNo.22の学生は, ファシリ テーターとしてチーム全員をコントロールすることで, 他のメンバーの能力向上を促すことができていたと示 唆され, 結果としては, 優秀チームとして選ばれなかっ たが, 学生No.22はファシリテーションの本質を十分に 理解することができていたのではないかと推測された. 一方で, ファシリテーター以外の他のメンバー間の相関 が無かった直接的な原因の特定には至らなかった。千 ームEでは, メンバー間の他己評価の相関が1つしか無 く,リーダーとファシリテーターの間に負の相関も見ら れた (図 $7 \mathrm{E}$ )。実際, 本チームではリーダーと長岡技 科大生との間にモチベーションのギャップが大きく, フ アシリテーターがそのギャップを埋めるための議論の 進行ができていなかったことが大きな要因であると考 えられた. チームFでも同様に, リーダーに対してファ シリテーターが遠慮をしている様子が見て取れた。加 えて, チーム唯一の女性である学生No.35が演習に対し て積極的に参加していなかったこと, 学科・学校の多 様性が低かったこと（女性, 学科, 学校の多様性の重 
表 2 アンケートC，D，Eにおける SNS 利用による教育効果と，プログラム全体におけるスキル向上効果（全体）

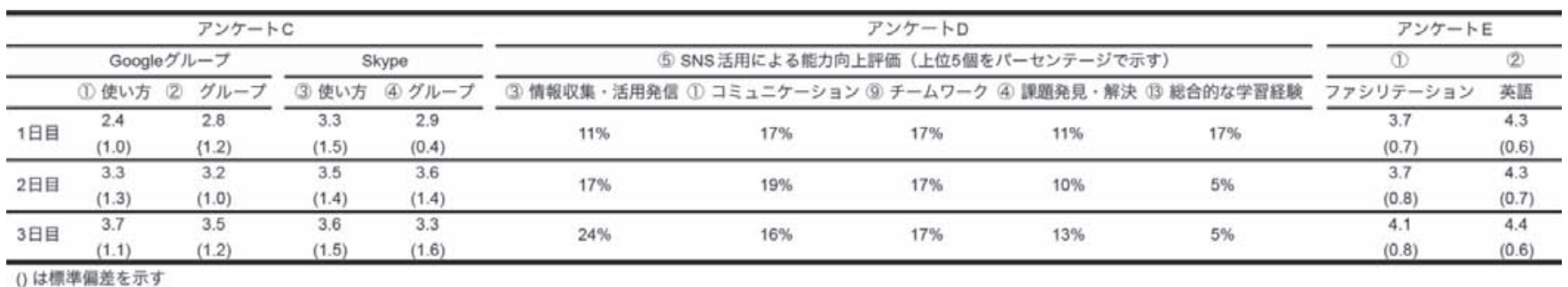

要性については後述）も要因として大きいと考えられ, その結果がネットワーク解析にも表れていた（図７Ｆ）.

6 チームに所属する 9 名の留学生のうち，6名の留 学生 (うち 2 名はプログラムの全日程に参加してないた め, 計算に含めず) は日本人学生と正の相関が見られ, ほとんどの留学生は 2 名以上の日本人学生と正の相関 を示した（図 7 )。そそのため, 他已評価の結果に基づく と, 本プログラムに参加した留学生と日本人学生がグル ープワークを通して交流することで, 国籍を超えて互い の成長を促すことができていると考えられた.

\section{SNS 利用による教育効果, プログラムにおけ るスキル向上効果と考察}

表 2 は, 3 日間に扔けるSNS 利用による教育効果と, プログラム全体に扔けるスキル向上効果を評価したア ンケート C, D, Eの結果を示す。学生には夜間の情報共 有・議論のために 2 種類の SNSツール (Googleグループ, Skype）を使わせ, これらSNSツールが学生のグループ ワークにとって有用であったかを評価させた. Googleグ ループは，メーリング・リストを簡単に作成でき, 更に, 参加メンバー間で議論を簡易的にできる優れたSNSで ある. 参加学生, 特に高専生は Googleグループの使い方 が分からない学生が多く, 初日の「Googleグループの基 本的な使い方の理解」で2.4 (5 段階評価) と低い值を示 した。一方, 2 日目からは, 学生間でも積極的に Google グループを活用する様子が見られ，使い方の理解に関し て3.4（2日目)，3.7 (3日目) と初日から著しく上昇し た.こういったSNS利用による教育効果を評価するた めに, 沉用的能力 13 項目の中から上位 3 つを学生に選択 させた（アンケートD, 表 2)。結果,「(3) 情報収集・活 用・発信」「「(1) コミュニケーション」,「(9) チームワー ク」,「(4) 課題発見・解決」,「13 総合的な学習経験」が 上位 5 個となった. (3), (1), (9)は想定される能力向上効 果であった一方で,「(4) 課題発見・解決」に関しては, 学生が情報収集・活用力, コミュニケーションやチーム ワークを駆使して, 課題を解決できていることを示唆し ており，ICT教育（情報通信技術を活用した教育方法） が学生の汎用的能力向上に効果的であると考えられた.

アンケートEの「(1) ファシリテーション基本を理解 し実践できたか」, 「(2) 英語が自分にとって身近なもの になったか」に関しては, 両方共に3.7以上と高い值を
示した（表 2)。3 日目には, (1), (2)それぞれ，4.1，4.4 とファシリテーションの理解・英語への親近感を感じ ていることが分かった，今回の合同演習では，意図的 に留学生が各6チームに入るようにしており, 学生が 汎用的能力だけでなく, 付加価值として, 議論をする ための基礎的な能力・英語の重要性の認識・英語能力 向上を促すことができたと考えられた（図 4 , 表 2 ).

\section{7. イノベーション指向型グローバル人材育成に} 向けたグループワークの評価

図 8 は, 本取り組みで形成された 6 チームの人多様 性を評価した結果を示す（PCA）。優秀チームとして 選ばれたチーム A と B は, クラスタを形成し, B. 学科 の種類, E. 学校の種類, G. 女性の数と正の相関を示し た. 一方で, 留学生の数と相関があまり見られなかっ た. その理由として, 各チームに最低 1 人の留学生が 所属しており，チーム間の違いが見られなかったため であると考えられる. また，英語力が堪能では無く， ファシリテーションの技術を学んだばかりの学生にと って, 1 チーム内の留学生の数・メンバーの数が多い ことはグループワークにとって必ずしも良いとは言え

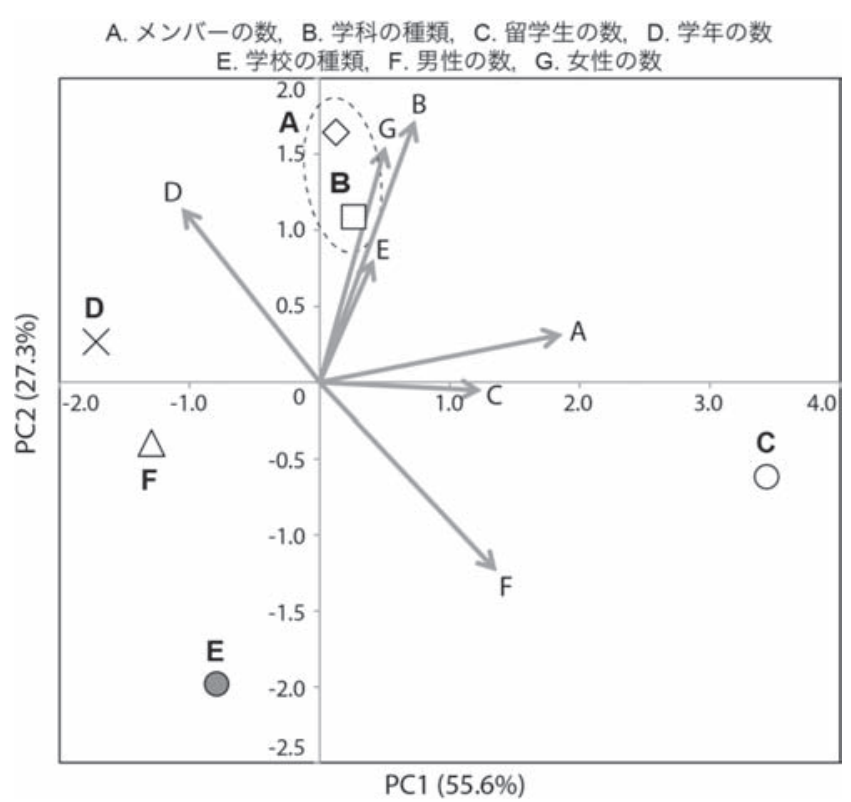

図 8 各チームの人多様性評価結果 太字の A - F は各学生チームの名称を示し, 矢印付 近の A - F は各チームと人多様性の相関を示す. 
ないことが, チームCのネットワーク解析及びPCAか ら示唆された（図 $7 \mathrm{C}$, 図 8 , メンバーの数, 留学生 の数と正の相関を示していた). 本結果は, 異なる学 校間でハッカソン型演習を行う際に, 学科 (専門性)・ 学校 (地域性)・性別の多様性確保が重要であることを 示しており，これらの多様性評価がグループのメンバ 一を決定するための指標となり得ると考えられた。

\section{8.おわりに}

今回の長岡技科大 - 高専が融合したイノベーション 指向型グローバル人材の育成を目的とした「イノベー ションアイデイアデザイン特別合同演習」では, 地域・ 年齢・国籍が異なる学生が集結し，世界規模のビジネ スニーズの共有や“イノベーション”を起こすための 技術を学ぶことに加え, 実際に学生が「イノベーショ ンアイデイア」をデザインすることで，今回目的とし た人材に必要不可欠な汎用的能力の向上を促すことが できた。加えて, 学生間のインターラクションをデー 夕に依って可視化することで, 多様な学生間の “化学 反応”を評価することができた。

本報の結果は, 地域・年齢・国籍・専門分野の異な る学生に, 成長のための “場”を提供することが, イ ノベーション指向型のグローバル人材育成に繋がるこ とを示した. 加えて, 異なる学校間で行うハッカソン 型演習による学生の成長促進のための 1 つの指標を提 案した。これらの結果は, 本報の取り組みが日本工学 教育における人材育成の 1 つのモデルとして幅広く適 用可能であることを示唆している. 今後, 参加した学 生がイノベーション指向型のグローバル人材として継 続的に切磋环磨できる環境を提供していくと共に，今 回成長した学生が地域に戻りカスケード反応を起こす 様子を追っていく予定である.

\section{謝辞}

本研究の一部は, 文部科学省国立大学改革強化推 進事業（三機関が連携・協働した教育改革）の助成を 受けた。また本研究を遂行するにあたり, Young Kim 氏，片桐恵氏に多大な協力を頂いた。 ここに記して感 謝の意を表する.

\section{参 考 文 献}

1）服部 賢：学理と実践の融合・技術科学大学の誕 生, 工学教育, $61-1$, pp. $15-19,2013$

2 ）小畑秀文：高専, これまでの半世紀とこれからの 半生記, 工学教育, $61-1$, pp.6-10, 2013

3 ）天野 徹：明日に挑戦する技術者を育成する高等 専門学校教育への期待, 工学教育, $61-1$, pp.3540, 2013

4 ) 三谷知世：海外から見た高専教育, 工学教育, 61 -
1, pp.153-156, 2013

5 ）黑田孝春：高専の国際交流の現状と今後期待され る国際支援, 工学教育, $61-1$, pp.74-78, 2013

6 ) 三機関 [長岡技術科学大学・豊橋技術科学大学 国立高等専門学校機構］が連携・協働した教育改 革, Webページ, http://www.nagaokaut.ac.jp/j/ annai/sankikan/, 参照日：2016-6-23

7 ）スーパーグローバル大学創生支援事業, Webぺ ージ, http://www.nagaokaut.ac.jp/j/annai/ sgweb/,参照日：2016-6-23

8 ) 斎藤秀俊: 技術科学大学に入学する高専生, 現在 そして未来, 工学教育, $61-1$, pp. $61-65,2013$

9 ) 長岡技術科学大学HP 留学生数, Webページ, http://www.nagaokaut.ac.jp/j/annai/ryugaku suu.html, 参照日：2016-6-23

10）山根淳平 : ハッカソンを一過性のイベントで終わ らせないために, 赤門マネジメント・レビュー, 13 - 12, pp.499-506, 2014

11）中村成芳, 山口剛士, 牧 慎也, 湯川高志, 山口隆 司, 市坪 誠:イノベーションを起こす自発型学習 リーダー育成のための多様性指向グループ演習, 工学教育, $64-2$, pp. $44-50,2016$

12）国立高等専門学校機構：モデルコアカリキュラム (試案), 2012

13) Ø. Hammer, D. A. T. Harper, P. D. Ryan : PAST: paleontological statistics software package for education and data analysis, Palaeontol Electronic, 4, pp.1-9, 2001

14) P. Shannon, A. Markiel, O. Ozier, N.S. Baliga, J.T. Wang, D. Ramage et al. : Cytoscape: A software environment for integrated models of biomolecular interaction networks, Genome Res, 13, pp.2498-2504, 2003

15）堀 公俊: 問題解決ファシリテーター:「ファシリ テーション能力」養成講座, 東洋経済新報社, 2003

16）横山真一郎：プロジェクトマネジメトのための基 礎教育, 工学教育, $61-5$, pp.10-15, 2013

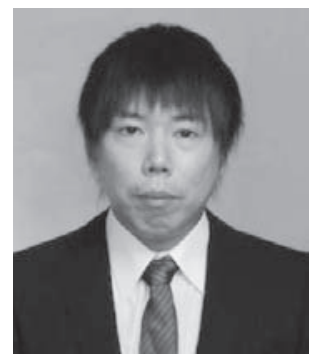

黒田 恭平

2013年 4 月 日本学術振興会特別研究員 制度 特別研究員 (DC 1$)$

2016年 4 月 北九州工業高等専門学校 生産デザイン工学科 特命 助教 (現職)

専門分野 環境工学, 分子生物学, 微生物 生態学, 工学教育

所属学会 公益社団法人土木学会. 日本水 環境学会, 日本微生物生態学会 